\title{
Research on Practical Teaching Forms of Ideological and Political Theory Course in Colleges
}

\author{
Yajuan Wang \\ Huanghe Science and Technology College \\ Zhengzhou, China 450006
}

\begin{abstract}
The single teaching form is one of the reasons why the effect of practical teaching of ideological and political theory course in colleges is not good. In order to reverse this situation, teachers who teach ideological and political theory course in colleges must truly change teaching concept, give full play to the dominant role of students in learning, base on the existing conditions of colleges and combine with the characteristics of each course respectively to actively explore diversified forms of practical teaching with remarkable teaching effect, in order to continuously strengthen the effectiveness of practical teaching of ideological and political theory course and promote its educational function.
\end{abstract}

Keywords-ideological and political theory course; practical teaching; forms

\section{INTRODUCTION}

One of the reasons why the effect of practical teaching of ideological and political theory course in colleges is not good is that the forms of practical teaching are single. In order to reverse this situation, teachers who teach ideological and political theory course in colleges must truly change teaching concept, turn "teacher-oriented" to "student-oriented", give fully play to the dominant role of students in learning, base on the existing condition in colleges, actively explore to make the forms of practical teaching become more diversified, the contents and links become closer to social practice, truly 'cultivate students' quality of caring about society and adapting to the society, let students learn to connect their future with the requirements of national development, find objective and direction that suit their development [1].", and make practical teaching "truly become the grand stage for every college student to transfer their knowledge into abilities and internalize them into quality" [2].

Looking from the space of students' practical activities, the forms of practical teaching of ideology and political theory course can be divided into classroom practical teaching, practical teaching on campus and off-campus practical teaching. There are a variety of specific and distinctive forms under them.

\section{ClaSSROOM PRACTICAL TEACHING}

\section{A. Classroom Debate}

According to propositions, the debate can be divided into theme-based debate and discovery type debate. The themebased debate is that the teacher bases on teaching objectives, combines with hot issues and focus issues in society and students' ideological reality to determine topic of the debate, such as "seeing the anti-corruption work of the party and the government from network anti-corruption", etc. After putting forward the topic, the teacher should leave enough time for students to look up references after school and ask students to speak and report in the next class. In the process of reporting, the teacher should encourage students to actively participate in and carry out further debate on problems appeared in the statement to form correct understanding. The discovery type debate refers to that the teacher does not assign topic of the debate, but let students put forward problems, then leave some time for them to look up references, analyze problems and write the outline of statement. In the next class, the teacher should let students speak and report to solve the problems. This kind of teaching method adheres to the viewpoint of "being no afraid of having no idea, but afraid of having no idea that one does not know", lets students review the systematic knowledge, look for confusion and put forward problems. On one hand, it can make students find out the confusions in their cognition; on the other hand, it can let the teacher actually understand what the students think, consider and confuse and make the teaching become more specific. No matter for the themebased debate or discovery type debate, in order to enlarge students' degree of involvement, the teacher should make positive guidance, not only pay attention to foiling the democratic atmosphere that the students dare to say, want to say and will say, but also prompt every student to actively participate in the activity and improve their ability in analyzing and solving problems through encouraging students to take the initiative to speak, restricting the specified statement and urging statement of test count.

It should be noticed that in classroom debate, the teacher should guide students to think instead of telling them the qualitative answers, just as the gardeners who prepare the soil, till, cultivate and clip instead of taking the place of plants to grow up. In this way, students' enthusiasm and 
initiative in learning can be fully aroused and their interests in acquiring knowledge can be stimulated.

\section{B. Students Give Lessons}

Letting students give lessons can realize the role exchange between teachers and students. In this way, the teacher can let students participate in the process of preparing lessons, looking up references, theoretical analysis and logical argumentation and it deepens students' understanding for the problems. In terms of students, preparing and giving lessons can train their abilities of looking up references, logical thinking and language expression and psychological quality, make students realize their deficiencies and promote their initiatives. In terms of teachers, letting students give lessons can help them to find out students' deficiencies in mastering the content, make the teaching become more targeted, and also find some original ideas in the presentation of students. The teaching benefits teachers as well as students. The contents of lessons given by students should conform to that the knowledge points are not very difficult for students and students are interested in it. The teacher assigns in advance, gives clear teaching requirements, reasonably divides students into groups according to the class size, requires all the groups make collective preparation for the lesson. The teacher should give some instructions for the methods of preparing lessons and the writing of teaching plan. Each group recommends one student to give lessons. Cooperative relationships appear in intra-groups and competitive relationships appear among groups. The teacher and the recommended student representative serve as the judges to assess according to the situations of teaching instruction and teaching plan of each group and reckon the marks in the performances at ordinary times of group members. It not only expands the scope of activity involvement, but also strengthens the team spirit, cooperative consciousness and sense of competition of students.

\section{Audiovisual Presentation}

Audiovisual materials integrate visual sense, auditory sense, emotional experience and reflections on life and make things and characters become vivid and dramatic. Special column programs such as Topics in Focus, News $1+1$ analyze social events and characters. Documentary films such as the Rise of the Great Powers and a Century China truly represent the history. Films such as the Creation of a World and My Long March depict historical events and historical figures. The perceptual intuition of these audiovisual materials brings visual and auditory impacts for us. It is easy for them to attract and appeal to students. Once the interests of students are aroused, it will produce inexhaustible power to make students be happy to learn, think and accept knowledge. The presentation of audiovisual materials is to serve the teaching objectives. We can say it is not only a kind of teaching pattern but also a teaching method to realize teaching objectives. So the teacher should not let students see them randomly, but organize students to discuss and express their opinions to realize teaching objectives. The presentation of audiovisual materials should pay attention to the following aspects: Firstly, it should be targeted and truly serve the teaching objectives. The second is principle of appropriate amount. Excessive audiovisual materials will easily lead to the weakening of theoretical knowledge. Thirdly, the teacher should pay attention to editing and combination of audiovisual materials. A teaching theme involves quite rich audiovisual materials, which cannot be presented in limited time. It requires the teacher to edit and combine audiovisual materials to form the combination effects, increase the shock power of audiovisual materials and systematicness of knowledge and truly realize the objective that audiovisual materials serve the teaching.

\section{Scenario Simulation}

Comenius, an educator in Czech Republic, once wrote in his Great Didactic that "All knowledge starts form the sense." Perceptual intuition can materialize and visualize the abstract knowledge and help students to form perceptual knowledge. The situational teaching method can make students be personally on the scene through showing vivid and specific images in front of students. Firstly, it makes students achieve abstract and rational sudden enlightenment from the visual perception; secondly, it arouses students' learning mood and interests in learning. Meanwhile, in emotional experience, scenario simulation can also train students' abilities in language expression, performance and adapting themselves to changing circumstances. For example, in the course of Ideological and Moral Cultivation and Basic Law Education, the teacher can open moot court in terms of one case. On one hand, it can make students get familiar with the procedure of judgment; on the other hand, it can also deepen students' thinking and application in legal knowledge. In the course of Mao Zedong Thought and Introduction to Theoretical System of Socialism with Chinese Characteristics, the teacher can design the scenario simulation such as the journalists in two sessions ask the premier problems. The students play the premier and the journalists. Through asking and answering interchangeably, it can help the teacher to further grasp students' ideological trend as well as arouse the enthusiasm of students to care about the worldly affairs and national conditions and make the relationships between students and the society become closer.

Classroom practical teaching has the characteristics that the teaching place and participants are fixed and the whole process is easy to control. So it becomes the first choice of many teachers who teach ideological and political theory course. But for students who study in the classroom all the year round, they have more interests in outdoor practice than classroom practice.

\section{PRACTICAL TEACHING ON CAMPUS}

\section{A. Visit and Learn}

Colleges should pay attention to developing off-campus practice teaching base. Meanwhile, they should also take full advantages of resources of their own, establish perfect practice base on campus, such as museum of school history, exhibition hall of school-based model teachers and students, and achievements of excellent schoolfellows. Depending on 
these practice bases, colleges can effectively make students visit and learn inside the school. The development of school is also an epitome of social development. Students can harvest abundant knowledge through visiting the museum of school history. Take the museum of school history in Huanghe Science and Technology College as an example. First of all, as members of the school, students can personally feel the development history of the school. It shortens the distance between school and students, makes people feel particularly close, enhances students' understanding for the school and greatly arouses their emotions of loving the school. Secondly, the development of school is an epitome of the reform and opening-up. Huanghe Science and Technology College starts from running a training class of self-study examination. Through nearly thirty years of development, it has become a teachingoriented undergraduate college that has 9 fields of disciplines such as engineering and literature, 13 secondary colleges, focuses on applied disciplines and harmonious development of multiple disciplines. The development of Huanghe Science and Technology College reflects the rapid development of non-government funded education and the brilliant achievements. Thirdly, the principal Hu Dabai is broken in body but firm in spirit and she has the hardworking and enterprising spirit. It greatly appeals to and educates students. The power of example is endless. Compared with other examples, the educational power beside us is incomparable.

\section{B. Thematic Association Activity}

Association activities in colleges are warmly welcomed by college students because it is easy for students to carry out and it is also colorful. They are the extra-curricular activities with the largest number of participants in colleges. It can meet the actual requirements of college students, arouse their enthusiasm of participation and make them receive education unconsciously to reach the effect of "moistening things silently". Therefore, teachers who teach the ideological and political theory course should depend on this platform, jointly consult with departments such as the Youth League Committee in the college and students' affairs office, extend the practical teaching of ideological and political theory course to the existing association activities in colleges, design and organize association activities with the theme of ideological and political education, such as knowledge contest, speech contest with the theme of loving my motherland China, class meeting with the theme of life plan, propaganda of saving resources and protecting the environment, implement the ideological and political education through students' association activities, prompt students to think about the teaching contents of ideological and political theory course, understand and internalize them to the ideas and beliefs of their own, and make college students grow up in practice. The effective implementation of thematic association activities makes it convenient for the forms of practical teaching of ideological and political theory course, enriches students' spare time life, and trains their abilities in participating in activities and strengthens their sense of competition.

\section{Special Lecture}

Special lecture is a good form of practical teaching of ideological and political theory course. It makes students can grasp detailed and related knowledge points in a relatively short period of time and expands the classroom based on theories. Compared with classroom teaching, narration on special topics and the narration of people who personally experience have the effects of theoretical education, emotional experience and moral education. The lecturers of the special lecture can be divided into two parts. One part is the people inside school, including teachers who teach the ideological and political theory course, Party committee of the school, publicists of the Youth League Committee. They can narrate special topics such as hot issues, focus issues in the world and countries. The other part is off-campus people. They are mainly specialists, scholars, old Red Army men, moral models and entrepreneurs invited by colleges. Invite scholars and specialists to explain the academic frontiers, analyze the Party's files and policies to help students to deepen their understanding; invite entrepreneurs to introduce the development history and cultural construction of enterprises, set up the bridge of connection between theory and practice and let students feel the tide of social development; invite characters of moral models to introduce advanced deeds, strengthen students' moral feelings and internalization; invite old Red Army men to tell things happened in revolution years to make students deeply understand the revolutionary spirit of persons of ideals and integrity in the revolution and the hard-won peace.

\section{Activities of Reading Good Books}

Groky said, "Books are the stepping stones to human progress". Books are the ocean of knowledge. Reading more books can make us know the ancient and the modern and have a good knowledge about the world. The richness in knowledge can make people enjoy the spiritual satisfaction. As a way of daily life of college students, reading books can help college students to systematically learn knowledge, broaden their horizons and enlighten them. Teachers who teach ideological and political theory course should give full play to the function of reading books and carry out practical teaching. It is well-known that to open a book is always beneficial. The embodiment of benefit depends on reading what kind of books. British novelist Fielding once said: a good book will guide you on the right direction, while a bad book will lead you to the hell. Zang Kejia said: Reading a good book is just like making a helpful friend. Teachers who teach ideological and political theory course have the responsibility and obligation to recommend this helpful friend to students, help students to grow up, integrate the ideological and political education in students' ways of daily life, recommend several good books to students in each semester, organize reading seminar, let students exchange their experience in reading and feel the charm of personality of great men in books, understand the reality of history and grasp the true meaning of knowledge..., let students truly benefit from it, expand their horizons and improve their political and ideological quality, cultural literacy and moral level. Besides, the more one reads, the better one writes. The activities of reading good books can greatly improve 
students' writing level and lay foundation for writing assignments of disciplines and graduation thesis.

\section{E. Network Teaching}

At present, the informatization develops rapidly, penetrates into every corner and occupies broad space. Campus network is the cultural front to attract college students. Therefore, teachers who teach ideological and political theory course should take the full advantage of attraction of internet culture on college students, and give play to the collective power of teachers, make efforts to build network educational platform of ideological and political theory course and enrich the forms of practical teaching. The construction of network educational platform of ideological and political theory course should conform to the following aspects. Firstly, they should set up resource library of ideological and political theory course, including teaching plan, courseware, exercises, audiovisual materials and reference books of various courses, to make it convenient for students' theoretical learning. Secondly, they should set up the news section, including major political news at home and abroad and campus news, to guide students to pay attention to and know about the society and the school. Thirdly, they should set up BBS interactive section, including BBS of current politics, learning center and life tips. The teachers should take turns on duty, take charge of viewing the post and replying to the post, give guidance on learning and life and timely help students to solve ideology confusion. The teachers make efforts to construct and improve, "truly turn the network educational platform of ideological and political theory course into a website welcomed by students and integrating ideological contents, theoretical property, interestingness and practicability ${ }^{[3]}$ ", and make it become an important platform of students' exchange of ideas, equal dialogue and psychological counseling.

Compared with off-campus practical teaching, practical teaching on campus has advantages such as relatively centralized range of students' activities, easy to manage and organize, without striking problems on expenditure and safety. Compared with classroom practical teaching, the range of students' activities is increased; it has strong real participation and intuition and students have higher interests in it. Therefore, teachers who teach ideological and political theory course should focus on researching and renovating practical teaching on campus.

\section{OfF-CAMPUS PRACTICAL TEACHING}

\section{A. Visit}

For the practical teaching of ideological and political theory course, the objects of off-campus practical visit can be divided into the following aspects. The first is to visit advanced units and excellent enterprises with typical reform, and understand remarkable achievements acquired in rural and urban economic development and social progress since the reform and opening-up. The second is to pay a visit to revolutionary shrine and old revolutionary base areas, give revolutionary traditional education to students, cherish the memory of great achievements of the old generation of proletarian revolutionists and firmly establish the faith of striving for the construction of socialism with Chinese characteristics. The third is to visit historical sites and cultural relics to cultivate students' national spirit and patriotic emotion. The fourth is to visit drug rehabilitation center and detention house to cultivate students' legal sense and behavior of abidance by law consciously. In order to ensure the effects of practical teaching, teachers who teach ideological and political theory course should: Firstly, actively guide students to look up reference books to provide knowledge base for the on-the-spot visit. Secondly, visit the site in advance, seriously analyze problems that may appear and seek for solutions to make the whole social practice activities in controllable scope. Thirdly, elaborately design the inspection plan, determine the purpose and requirements, and emphasize precautions and strengthen students' safety awareness. Fourthly, make it clear about the feedback of inspection results and evaluate students' performance, including performance reflected by the results, and the attitude, degree of participation, team spirit and consciousness of innovation. The teacher should make comprehensive evaluation as far as possible.

\section{B. Social Research}

The objective of theoretical learning is application. Social research is an important way to improve the abilities of college students in analyzing and solving problems. Teachers who teach ideological and political theory course should base on the contents and teaching objectives of the course, guide students to seriously choose and elaborately design the research topic. The establishment of frontier, scientific and representative research topic is the beginning of a successful social research. The design of theme should not only consider students' knowledge, ability, social experience and major, but also reflect the hot issues and focus issues in society. The teacher should prepare several topics for students to freely choose. It can fully arouse students' interests and makes the research become feasible. The social research is often carried out in holidays and finished by groups of students or students independently. The dispersion of students requires the teacher to give systematic and specific guidance in advance about the precautions, research methods, writing forms and requirements of research report to make students' research activities have rules to follow. After students hand in the research reports, the teacher should carefully read over and give remarks, make scientific evaluation to give feedbacks to students such as praise students' achievement and points out their deficiencies to further improve students' levels of social research. Social practice not only strengthens students' consciousness of linking theory with practice, but also deepens the knowledge and trains students' abilities of social communication and dealing with affairs.

\section{Social Practice}

The degree of internalization of theory, and the transformation degree of political accomplishment and moral character can be embodied through the externalization of behaviors. Teachers who teach ideological and political theory course should actively organize and encourage 
college students to participate in social activities for public good and youth volunteer activities to carry out compulsory publicity and services. The teacher can organize students to carry out law dissemination, propaganda such as "protect the environment and save resources" and social morality, and activities of preaching the Party's policies and guidelines in school and communities and let students use the learned knowledge to better serve the society. Besides, they can also organize students to bus stations to maintain the order of getting on, do some cleaning and serve the passengers; go to children welfare association to play with orphans and teach them to learn culture and tell stories for them; let students inherit and carry forward the benevolence spirit of Chinese nation and excellent moral tradition of helping others, cultivate students' sense of responsibility and benevolence and strengthen their ideological and moral cultivation.

Off-campus practical teaching is always welcomed by college students because of its broad space and flexible form. But the characteristics of off-campus practice such as the openness of space, randomness of students' activities and the uncertainty of process of activities also have higher requirements for teachers who teach ideological and political theory course, require them to continuously strengthen and improve the ability of organization and management, coordinated ability and ability of emergency management.

\section{CONCLUSION}

In conclusion, the practical teaching uses its openness and flexibility to greatly arouse the enthusiasm of students. It needs teachers who teach the course of ideological and political theory course to seriously research and strengthen the innovation and explore according to characteristics of various courses such as ideological and political theory course, specifically determine the specific topics for practical teaching of various courses and choose effective forms of practical teaching, in order to strengthen the effectiveness of practical teaching and promote its educational function.

\section{REFERENCES}

[1] Wu Shaoyu, Liu Shihua. Discussion on the Connotation and Links of Practical Teaching of Ideological and Political Theory Course [J], Heilongiiang Researches on Higher Education, 2008(5): 169

[2] Zhao Xia. Limitation of Mode of College Students' Social Practice and Its Transcendence [J], Jiangsu Higer Education, 2007(5): 110

[3] Tang Jingcheng. Exploration on Network Practical Teaching of Ideological and Political Theory Course in Collges [J], Journal of Ankang University, 2010(6):110 